\title{
NGHIÊN CỨU HIỆN TRẠNG Ô NHIẼ̃M VÀ ĐỀ XUẤT CÁC GIẢI PHÁP BẢO VÊ CHẤT LƯợNG NƯỚC MẠTT TRÊN ĐỊA BÀN HUYỆN XUẤN LỘC, TỈNH ĐỒNG NAI
}

\author{
LÊ VIẸTT THẮNG ${ }^{1}$, NÔNG VĂN KHÁNH ${ }^{2}$ \\ ${ }^{1}$ Trường Đại học Công nghiệp Thành phố Hồ Chí Minh, \\ ${ }^{2}$ Công ty CP VBĐQ Phú Nhuận \\ levietthang@iuh.edu.vn,khanhzilei@gmail.com
}

\begin{abstract}
Tóm tắt. Huyện Xuân Lộc, Đồng Nai có vai trò quan trọng trong quá trình xây dựng phát triển kinh tế xã hội của địa phương, những năm gần đây tốc độ phát triển kinh tế được đẩy nhanh, đi đôi với quá trình phát triển sẽ nảy sinh những tác động tiêu cực, làm ảnh hưởng tới tài nguyên và môi trường tại khu vực. Việc nghiên cứu hiện trạng ô nhiễm, xác định các nguồn gây ô nhiễm, từ đó đề xuất các giải pháp nhằm ngắn ngừa, hạn chế tác động xấu đến nguồn nước mặt huyện Xuân Lộc, Đồng Nai là cần thiết và cấp bách. Dựa trên phương pháp đo đạc, lấy mẫu phân tích hiện trạng môi trường, tính toán chỉ số chất lượng nước, thu thập thông tin từ phiếu điều tra, tính toán tải lượng ô nhiễm các nguồn thải: chăn nuôi heo, cơ sở sản xuất,...Kết quả nghiên cứu cho thấy: Chất lượng nước mặt của huyện Xuân Lộc có dấu hiệu ô nhiễm về hàm lượng chất hữu cơ (BOD5, COD), chất dinh dưỡng (Nitrit, Nitrat, Amôni, Phosphat) và vi sinh (Coliform). Vào mùa khô các thông số ô nhiễm cao hơn so với mùa mưa. Hoạt động chăn nuôi heo là nguồn phát sinh lưu lượng và tải lượng ô nhiễm nhiều nhất và gấp nhiều lần so với các nguồn thải khác. Từ kết quả điều tra, phân tích, bài nghiên cứu đã đưa ra các giải pháp thiết thực nhằm giảm thiểu, ngăn ngừa, hạn chế tác động xấu đối với môi trường nước mặt tại khu vực Xuân Lộc, Đồng Nai.
\end{abstract}

Từ khóa. Chăn nuôi heo, chất lượng nước, nguồn thải, Đồng Nai.

\section{STUDY ON POLLUTION AND PROPOSED SOLUTIONS PROTECTING WATER QUALITY IN LOCAL AREA OF XUAN LOC DISTRICT, DONG NAI PROVINCE}

\begin{abstract}
Abtract. Xuan Loc district, Dong Nai province have an important role in the process of building socioeconomic development of the locality. In recent years, the speed of economic development has accelerated, coupled with the development process will be bouncing. Negative impacts, affecting the resources and environment in the area. The study on the current status of pollution, identifying sources of pollution and propose solutions to prevent and limit negative impacts on the environment of Xuan Loc district, Dong Nai province is necessary and urgent. Based on the method of measurement, sampling for analyzing the current state of the environment, calculating the water quality index, gathering information from the questionnaire, calculating the pollutant discharge load of the waste sources: pig raising, research results show that surface water quality of Xuan Loc district shows signs of pollution of organic matter (BOD5, COD), nutrients (Nitrite, Nitrate, Ammonium, Phosphate) and microorganisms (Coliform). In the dry season, the pollution parameters are higher than the rainy season. In fact, pig farming is the most polluting and polluting discharge source and is several times more than other sources. From the results of the survey, analysis and research papers, there are practical solutions to minimize, prevent and limit bad impacts on the environment in Xuan Loc district, Dong Nai province.
\end{abstract}

Keywords. Pig raising, water quality, waste source, Dong Nai.

\section{1 ĐẶT VẤN Đề}

Những năm gần đây tốc độ phát triển kinh tế được đẩy nhanh, đi đôi với quá trình phát triển kinh tế sẽ nảy sinh những tác động tiêu cực, làm ảnh hưởng tới tài nguyên và môi trường, nghiên cứu "Quản lý thống nhất và tổng hợp các nguồn thải gây ô nhiễm trên lưu vực hệ thống sông Đồng Nai” của tác giả Huỳnh Thị 
Minh Hằng và cộng sự (2006) [8] cho thấy những vấn đề bức xúc về môi trường nước trên lưu vực hệ thống sông Đồng Nai, nhận diện và sơ bộ đánh giá các nguồn thải gây ô nhiễm chính trên lưu vực, từ đó xây dựng và đề xuất các tiêu chí phân loại, đánh giá các nguồn thải. Kết quả nghiên cứu cho thấy trên lưu vực hệ thống sông Đồng Nai đang tiếp nhận các nguồn thải từ các khu đô thị, các khu công nghiệp tập trung, phân tán, từ các bãi rác trên lưu vực. Hiện nay trên lưu vực hệ thống sông Đồng Nai cũng đang diễn ra mâu thuẫn hết sức gay gắt giữa các mục tiêu khai thác và sử dụng nguồn nước để phát triển kinh tế - xã hội hiện tại với các mục tiêu bảo vệ, quản lý nguồn nước để sử dụng về lâu dài. Vì vậy cần quản lý tổng hợp các nguồn thải và xây dựng hệ cơ sở dữ liệu môi trường lưu vực sông nhằm hỗ trợ cho việc ra quyết định chính xác và kịp thời. Lê Mạnh Tân, Đinh Quang Toàn [10] đã đánh giá tổng quan nguồn thải gây ô nhiễm trên lưu vực hệ thống sông Đồng Nai đoạn qua tỉnh Bình Dương. Kết quả cho thấy các nguồn thải gây ô nhiễm chính lên hệ thống sông Đồng Nai đoạn qua tỉnh Bình Dương là từ các khu công nghiệp, nước thải sinh hoạt, nước thải từ quá trình sản xuất nông nghiệp đã tác động đến chất lượng nước và đang có dấu hiệu bị

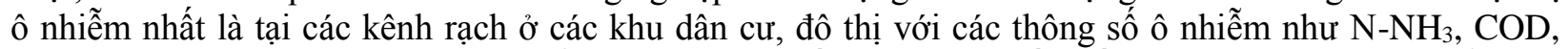
BOD. Nghiên cứu mới chỉ đánh giá tổng quan các nguồn thải, chưa đề xuất các biện pháp giảm thiểu, cải thiện chất lượng nước sông đoạn qua Bình Dương. Sư phát triển của kinh tế kéo theo tốc độ quá trình đô thị hóa và công nghiệp hóa diền ra khá nhanh. Các khu, cụm công nghiêp, các cơ sở sản xuất, nằm xen lẫn các khu dân cư và xả thải không qua xử lý hoặc những trang thiết bị xử lý không đạt tiêu chuẩn, không đáp ứng được quy định về xả thải đều xả trực tiếp ra môi trường làm ảnh hưởng đến môi trường không khí đặc biệt là môi trường nước. Kết quả nghiên cứu cho thấy các hoạt động kinh tế xã hội đã tác động đến chất lượng nước sông Phan bị ô nhiễm nghiêm trọng do tiếp nhậ nguồn thải từ chăn nuôi, khu dân cư, đô thị ven sông [9]. Một nghiên cứu ở Nghệ An sử dụng chỉ số chất lượng nước WQI để đánh giá chất lượng môi trường nước tại 43 điểm quan trắc nước mặt trên địa bàn tỉnh Nghệ An. Kết quả cho thấy chất lượng nước bị ô nhiễm với $44 \%$ số mẫu bị ô nhiễm nặng, $30 \%$ chất lượng thấp và chỉ có $26 \%$ có thể sử dụng cho mục đích sinh hoạt. Chỉ có $26 \%$ mẫu có thể sử dụng cho mục đích sinh hoạt. Nguyên nhân ô nhiễm được xác định chủ yếu bởi hàm lượng TSS quá cáo, ngoài ra $\mathrm{DO}, \mathrm{BOD}, \mathrm{COD}, \mathrm{NH}_{4}$ không đáp ứng yêu cầu của Quy chuẩn ở mức A2 [7]. Nhìn chung, chưa có đề tài nào nghiên cứu chi tiết về hiện trạng chất lượng môi trường, các nguồn gây ô nhiễm, cũng như các giải pháp bảo vệ tài nguyên và môi trường riêng cho địa phương.

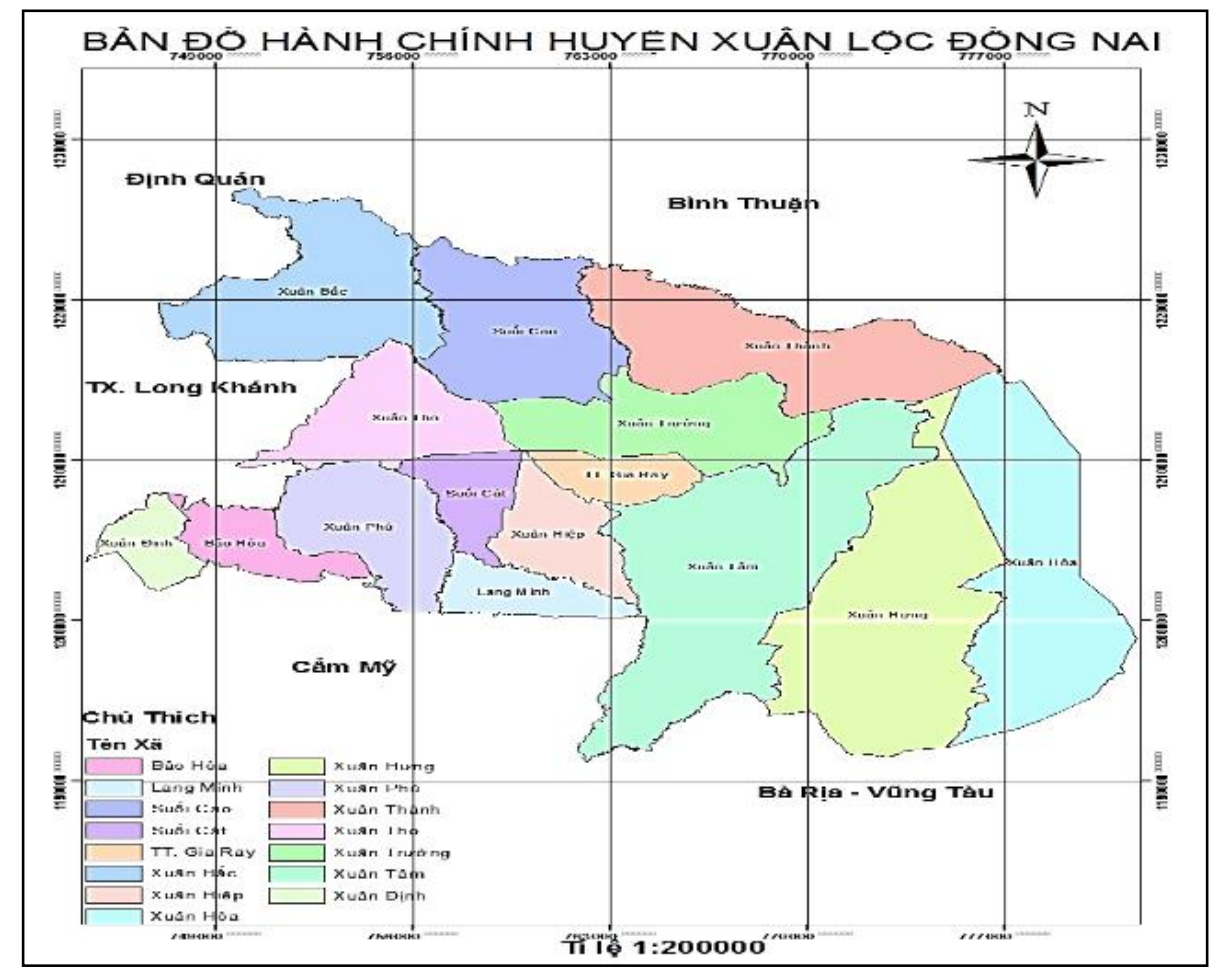

Hình 1. Bản đồ huyện Xuân Lộc, Đồng Nai 


\section{NGHIÊN CUUU HIÊN TRẬ Ô NHIỄM VÀ ĐÊ XUÂTT CÁC GIẢI PHÁP BẢO VỆ CHẤT LƯợNG NƯỞC MẶT TRÊN ĐỊA BÀN HUYỆN XUÂN LỘC, TỈNH ĐỒNG NAI}

Huyện Xuân Lộc với diện tích tự nhiên toàn huyện là 727,19km² gồm 02 sông lớn là Sông La Ngà, Sông Ray, ngoài ra còn các sông nhánh thuộc hệ thống sông Dinh. Kết quả điều tra cho thấy nguồn thải chính tác động trực tiếp, gián tiếp đến môi trường nước mặt huyện Xuân Lộc từ hoạt động chăn nuôi. Bên cạnh đó các nguồn thải khác cũng góp phần làm gia tăng ô nhiễm tại khu vực như: nguồn thải sinh hoạt từ hoạt động của dân cư, các hoạt động sản xuất, các cơ sở dịch vụ: chợ, y tế, quán ăn. Việc giảm thiểu các tác động tiêu cực đến môi trường do các nguồn gây ô nhiềm đến nước mặt nhằm đảm bảo phát triển bền vững kinh tế - xã hội khu vực là cần thiết và cấp bách. Bài nghiên cứu này trình bày về kết quả khảo sát, phân tích và đánh giá hiện trạng chất lượng nước mặt một số sông, suối, hồ, nguyên nhân gây ô nhiễm và đề xuất các giải pháp thiết thực bảo vệ chất lượng nước mặt của huyện.

\section{NỘI DUNG VÀ PHƯƠNG PHÁP NGHIÊN CÚU}

\subsection{Phạm vi và đối tượng nghiên cứu}

Phạm vi nghiên cứu là khu vực huyện Xuân Lộc, Đồng Nai với diện tích tự nhiên khoảng 727,19km² bao gồm 1 thị trấn và 14 xã. Nghiên cứu chất lượng nước các sông, suối, hồ chính trên địa bàn huyện Xuân Lộc, tỉnh Đồng Nai.

\subsection{Nội dung và phương pháp nghiên cứu}

Nội dung nghiên cứu: Nghiên cứu hiện trạng ô nhiễm, đánh giá các nguồn thải chính trên địa bàn và đề xuất các giải pháp bảo vệ chất lượng nước mặt trên địa bàn huyện Xuân Lộc, tỉnh Đồng Nai.

Phương pháp nghiên cứu

(1) Phương pháp phân tích số liệu điều tra

Sử dụng phần mềm xử lý số liệu excel để tiến hành thống kê, tính toán số liệu các nguồn thải. Và biểu diễn số liệu phân tích tính toán qua biểu đồ.

(2) Phương pháp khảo sát thực địa và lựa chọn vị trí lấy mẫu

Lựa chọn vị trí lấy mẫu nước mặt: Mẫu nước mặt được lấy tại một số sông, suối, hồ chính trên địa bàn huyện. Vị trí lấy mẫu nước mặt được lựa chọn theo tiêu chí sau: (a) Khu vực chịu tác động của các nguồn thải; (b) Tại các điểm hợp lưu của sông, suối trong khu vực nghiên cứu. Vị trí lấy mẫu nước mặt được trình bày ở bảng 1 .

Lưa chọn nguồn xả thải điều tra: Phối hợp với Phòng Tài nguyên và Môi trường huyện Xuân Lộc để xác định danh sách nguồn thải. Các nguồn thải được lựa chọn ưu tiên theo tiêu chí sau: (a) Xả thải trực tiếp ra sông suối, hồ; (b) Phát sinh nước thải với lưu lượng lớn.

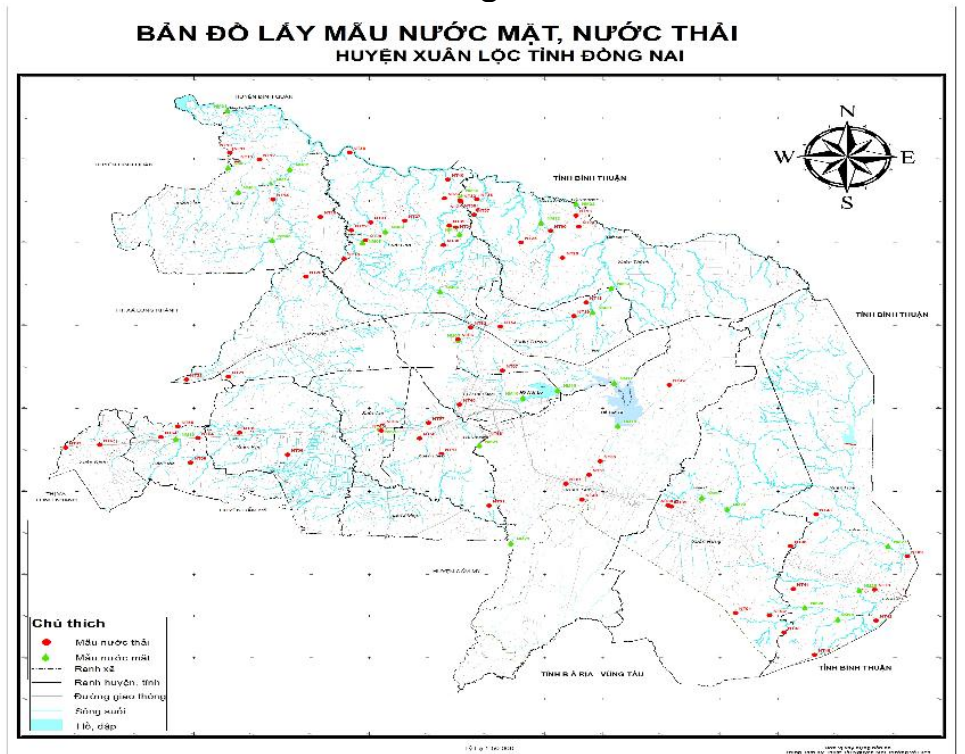

Hình 2. Bản đồ lấy mẫu nước mặt và nước thải huyện Xuân Lộc 
Bảng 1. Vị trí lấy mẫu nước mặt huyện Xuân Lộc

\begin{tabular}{|c|c|c|c|c|c|}
\hline \multirow{2}{*}{ TT } & \multirow{2}{*}{$\begin{array}{c}\text { Ký } \\
\text { hiệu }\end{array}$} & \multirow{2}{*}{ Tên mẫu } & \multirow{2}{*}{ Vị trí lấy mẫu } & \multicolumn{2}{|c|}{ Tọa độ lấy mẫu } \\
\hline & & & & $\mathbf{X}$ & $\mathbf{Y}$ \\
\hline 1 & NM01 & Sông La Ngà & $\begin{array}{l}\text { Khu vực giao giữa đường Thanh Sơn-Xuân Bắc và } \\
\text { sông La Ngà }\end{array}$ & 451426 & 1225429 \\
\hline 2 & NM02 & Suối Rết & $\begin{array}{l}\text { Khu vực giao giữa đường Xuân Thành-Suối-Cao- } \\
\text { Xuân Bắc và suối Rết }\end{array}$ & 454103 & 1221897 \\
\hline 3 & NM03 & Suối Lạnh & $\begin{array}{l}\text { Khu vực giao giữa đường vào suối Lạnh, qua KDC, } \\
\text { tiếp nhận nước thải sinh hoạt và nước thải chăn nuôi } \\
\text { của các hộ chăn nuôi nhỏ lẻ }\end{array}$ & 461301 & 1211623 \\
\hline 4 & NM04 & Suối Tre & Giao nhau giữa đường TL 763 và suối Tre & 451906 & 1220527 \\
\hline 5 & NM05 & Suối Rết & $\begin{array}{l}\text { Nhánh sông của đập suối Rết chảy vào khu dân cư } \\
\text { giao với TL } 763\end{array}$ & 453355 & 1217611 \\
\hline 6 & NM06 & Suối nhỏ Suối Cao & Đoạn qua cầu Gia Lào - Suối Cao - Xuân Lộc & 460535 & 1214537 \\
\hline 7 & NM07 & Suối Tà Rùa & Nằm trên suối Tà Rùa xã Xuân Bắc & 451463 & 1221996 \\
\hline 8 & NM08 & Suối Mè & $\begin{array}{l}\text { Khu vực gần đường Suối Mè, tiếp nhận nước thải } \\
\text { Trang trại heo Nguyệt Đức }\end{array}$ & 457214 & 1217479 \\
\hline 9 & NM09 & Suối Mè & $\begin{array}{l}\text { Khu vực gần đường Suối Mè, tiếp nhận nước thải } \\
\text { Trang trại chăn nuôi Đỗ Minh Tuấn }\end{array}$ & 458196 & 1218139 \\
\hline 10 & NM10 & $\begin{array}{l}\text { Cầu số } 1 \text { (Giao đường } \\
\text { Xuân Thành - Suối } \\
\text { Cao - Xuân Bắc) }\end{array}$ & $\begin{array}{l}\text { Thượng nguồn ra sông La Ngà: Nơi tiếp nhận nước } \\
\text { thải Trại heo Xuân Thành } 2 \text { và Trại heo Công ty } \\
\text { Dolico }\end{array}$ & 461389 & 1220349 \\
\hline 11 & NM11 & Suối Nhỏ Suối Cao & $\begin{array}{l}\text { Đoạn chảy vào suối Gia Huynh, tiếp nhận nước thải } \\
\text { Trại heo Công ty Dolico }\end{array}$ & 461374 & 1217983 \\
\hline 12 & NM12 & Suối Lò Cỏ & $\begin{array}{l}\text { Đoạn chảy vào suối Gia Huynh, tiếp nhận nước thải } \\
\text { chăn nuôi heo và nhà máy sản xuất bột mì Tân Hợp } \\
\text { Thành }\end{array}$ & 464865 & 1218671 \\
\hline 13 & NM13 & Suối Khỉ & Giao giữa đường Xuân Thành-Trảng Táo, Suối Khỉ & 467873 & 1214749 \\
\hline 14 & NM14 & Suối Tam Bung & Cầu Suối Tam Bung & 453283 & 1221017 \\
\hline 15 & NM15 & Hồ Núi Le & Thượng nguồn vào hồ Núi Le & 464088 & 1208126 \\
\hline 16 & NM16 & Hồ Núi Le & Trên hồ Núi Le gần cống xả & 465548 & 1208277 \\
\hline 17 & NM17 & Hồ Gia Ui & Trên hồ Gia Ui gần cống xả & 468023 & 1208824 \\
\hline 18 & NM18 & Hồ Gia Ui & Trên hồ Gia Ui & 468284 & 1208011 \\
\hline 19 & NM19 & Suối Nhỏ Bảo Hòa & Trên tuyến đường QL1A, gần UBND xã Bảo Hòa & 449223 & 1205654 \\
\hline 20 & NM20 & Suối Nhỏ Suối Cát & Trên đường QL1A và cầu suối Cát & 457927 & 1206308 \\
\hline 21 & NM21 & Suối Gia Măng & Trên đường vào suối Gia Măng & 462221 & 1205290 \\
\hline 22 & NM22 & Suối Gia Huynh & Đoạn giáp ranh tỉnh Bình Thuận & 466362 & 1219837 \\
\hline 23 & NM23 & Sông Ray & Thượng nguồn hồ Sông Ray & 463570 & 1199384 \\
\hline 24 & NM24 & Suối Oi & Giao nhau giữa đường suối cầu và Suối Oi & 472824 & 1201436 \\
\hline 25 & NM25 & Suối Bà Rùa & $\begin{array}{l}\text { Giao nhau giữa suối Bà Rùa và đường Bảo Hòa- } \\
\text { Xuân Hòa }\end{array}$ & 478480 & 1196553 \\
\hline 26 & NM26 & Suối Bà Rùa & Trên đường vào suối Bà Rùa & 476154 & 1195509 \\
\hline 27 & NM27 & Suối Gia Ui & Trên suối Gia Ui & 479703 & 1199198 \\
\hline 28 & NM28 & Suối Cầu & $\begin{array}{l}\text { Đoạn tiếp nhận nước thải chăn nuôi tập trung xã } \\
\text { Xuân Hòa }\end{array}$ & 477567 & 1194789 \\
\hline 29 & NM29 & Suối Khỉ & $\begin{array}{l}\text { Đoạn tiếp nhận nước thải chăn nuôi trại heo Kim } \\
\text { Ngọc Phan }\end{array}$ & 467058 & 1213297 \\
\hline 30 & NM30 & Sông Ui & Đoạn chảy qua KDC Xuân Hưng & 471725 & 1202124 \\
\hline
\end{tabular}




\section{NGHIÊN CƯU HIÊN TRANG Ô NHIỄM VÀ ĐỀ XUẤT CÁC GIẢI PHÁP \\ BẢO VỆ CHẤT LƯợNG NƯỞC MẶT TRÊN ĐỊA BÀN HUYỆN XUÂN LỘC, TỈNH ĐỒNG NAI}

\section{(3) Phương pháp điều tra, phỏng vấn}

Thực hiện khảo sát và thu thập thông tin các nguồn thải trong khu vực huyện Xuân Lộc tỉnh Đồng Nai bằng phiếu điều tra, với tổng số phiếu là 200 , bao gồm: cơ sở chăn nuôi - giết mổ gia súc gia cầm, cơ sở sản xuất và chế biến, cơ sở dịch vụ (chợ, nhà hàng - quán ăn, $\mathrm{y}$ tế, khách sạn). Riêng nguồn thải từ hoạt động chăn nuôi heo, có lưu lượng thải lớn và rất nhiều cơ sở, hộ chăn nuôi, vì vậy để đánh giá chính xác đầy đủ về tác động của nguồn thải này đến chất lượng môi trường nước mặt huyện Xuân Lộc, ngoài việc điểu tra tại nguồn thải, nhóm nghiên cứu tiến hành thu thập thêm thông tin chung về hoạt động chăn nuôi tại từng đơn vị hành chính của huyện để đưa ra những kết quả xác thực nhất. Các thông tin thu thập gồm: Ngành nghề, toạ độ địa lý, lưu lượng xả thải, công nghệ xử lý, biện pháp bảo vệ môi trường....

\section{(4) Phương pháp khảo sát hiện trường, lấy mẫu và phân tích}

Phương pháp khảo sát hiện trường, lấy mẫu phân tích

Vị trí và tần suất lấy mẫu: lấy mẫu tại 30 vị trí với 4 đợt (2 đợt vào mùa mưa, 2 đợt vào mùa khô) vào mùa khô $(5 / 2017,6 / 2017)$ vào mùa mưa $(8 / 2017,9 / 2017)$. Thông số phân tích nước mặt: $\mathrm{pH}, \mathrm{DO}, \mathrm{TSS}$, COD, BOD5, N-NH4+, T-N, T-P, Nitrite, Nitrate, Phosphat, Coliform.

Mẫu nước thải: khảo sát và lấy mẫu phân tích 70 mẫu với các chỉ tiêu được phân tích là: $\mathrm{pH}$, TSS, COD, BOD5, N-NH4+, T-N, T-P, Nitrite, Nitrate, Phosphat, Coliform.

Phương pháp lấy mẫu: Theo các Tiêu chuẩn lấy mâ̂u hiện hành: Lấy mẫu nước thải TCVN 5999:1995 (ISO 5667-10:1992). Lấy mẫu khảo sát, phân tích các chỉ tiêu môi trường để đánh giá chất lượng nước thải phát sinh tại các cơ sở sản xuất, kinh doanh, dịch vụ và chăn nuôi trên địa bàn huyện Xuân Lộc; Lấy mẫu nước sông, suối, hồ TCVN 6663-6:2008 (ISO 5667-6:2005).

Phương pháp phân tích: phân tích theo TCVN 6492 - 2011, TCVN 6180:1996, theo Standard Methods for the Examination of Water and Wastewater (SMEWW)

\section{(5) Phương pháp tính toán tải lượng tải lượng chất ô nhiễm}

Tải lượng chất ô nhiễm = Lưu lượng $\mathrm{x}$ nồng độ chất ô nhiễm.

Hoặc công suất hoạt động sản xuất $\mathrm{x}$ hệ số ô nhiễm

(6) Phương pháp tính toán chất lượng nước WQI [3]

Theo Quyết định số 879 /QĐ-TCMT ngày 01 tháng 7 năm 2011 của Tổng cục trưởng Tổng cục Môi trường. Bao gồm các thông số: $\mathrm{pH}, \mathrm{DO}, \mathrm{TSS}$, amoni, photphat, $\mathrm{BOD}_{5}, \mathrm{COD}$, coliforms, nhiệt độ.

\section{KẾT QUẢ VÀ THẢO LUẬn}

\subsection{Hiện trạng chất lượng nước mặt huyện Xuân Lộc}

\subsection{1 Đánh giá các thông số hóa lý}

Bảng 2. Thể hiện nồng độ các thông số hóa lý trong nước mặt huyện Xuân Lộc

\begin{tabular}{|c|c|c|c|c||c|c|c|c|}
\hline \multirow{2}{*}{ Thông số } & \multicolumn{4}{|c||}{ Mùa khô } & \multicolumn{4}{c|}{ Mùa mưa } \\
\cline { 2 - 9 } & Mean & Std & Min & Max & Mean & Std & Min & Max \\
\hline $\mathrm{pH}$ & 7,46 & 0,61 & 6,31 & 8,62 & 7,50 & 0,66 & 6,35 & 8,66 \\
\hline TSS $(\mathrm{mg} / \mathrm{l})$ & 82,0 & 73,97 & 6 & 350 & 40,05 & 34,54 & 5 & 209 \\
\hline DO $(\mathrm{mg} / \mathrm{l})$ & 3,87 & 1,91 & 0 & 7,4 & 5,52 & 1,62 & 0,9 & 9,6 \\
\hline
\end{tabular}

pH tại các vị trí quan trắc dao động không đáng kể theo mùa: Trung bình vào mùa khô dao động từ $7,46 \pm 0,61$ và mùa mưa dao động từ 7,50 $\pm 8,66$. Tất cả các vị trí đều đạt QCVN 08:2015-MT /BTNMT về nước mặt cột $\mathrm{A} 2$.

Tổng chất rắn lơ lửng (TSS): Nồng độ chất rắn lơ lửng có giá trị trung bình trong nước mặt có giá trị trung bình $82,0 \pm 73,97(\mathrm{mg} / \mathrm{l})$ vào mùa khô và có giá trị 40,05 $\pm 34,54(\mathrm{mg} / \mathrm{l})$ vào mùa mưa. Các vị trí có nồng độ SS cao tập trung tại các nhánh suối tiếp nhận nước thải từ các trang trại chăn nuôi lớn như: Suối Lạnh (NM03), Suối nhỏ Suối Cao (NM06), Suối Mè (NM09), nhánh suối Gia Huynh (NM11, NM12), Suối Cầu (NM28) và Suối Khỉ (NM29). Tại 2 hồ cung cấp nước sinh hoạt (Hồ Núi Le và Hồ Gia Ui) khi so sánh 
với QCVN 08:2015-MT/BTNMT cột A2 (30 mg/l) cho thấy hầu hết tại các vị trí lấy mẫu ở các đợt vào mùa khô và mùa mưa nồng độ $\mathrm{SS}$ đều đạt quy chuẩn cho phép

Oxy hòa tan $(\mathrm{DO})$ : Kết quả phân tích nồng độ oxy hòa tan có giá trị trung bình $3,87 \pm 1,91(\mathrm{mg} / \mathrm{l})$ vào mùa khô và có giá trị $5,52 \pm 1,62(\mathrm{mg} / \mathrm{l})$ vào mùa mưa. Nồng độ $\mathrm{DO}$ trong nước tăng lên vào mùa mưa. So sánh với QCVN 08:2015-MT/BTNMT cột A2 ( $\geq 5 \mathrm{mg} / \mathrm{l})$, cho thấy: Đợt 1 mùa khô có 19/27 vị trí, đợt 2 mùa khô có $16 / 30$ vị trí, đợt 1 mùa mưa có $9 / 30$ vị trí, đợt 2 mùa mưa có $10 / 30$ vị trí không đạt quy chuẩn. Nguyên nhân là các vị trí nhánh suối tiếp nhận trực tiếp nước thải chăn nuôi từ các hộ và trang trại chăn nuôi lớn, không có dòng chảy, tù đọng và cạn nước làm khả năng tự làm sạch kém dẫn đến gia tăng các chất ô nhiễm, giảm hàm lượng oxy hòa tan. Trong đó, hàm lượng oxy hòa tan thấp nhất tại các vị trí NM06, NM08, NM09, NM11, NM12, NM28, NM29 vào mùa khô đều có giá trị dưới 3 mg/l. Hàm lượng DO tại Hồ Núi Le và Hồ Gia Ui đa số đều đạt QCVN 08:2015-MT/BTNMT cột A2 ( $\geq 5 \mathrm{mg} / \mathrm{l})$,

\subsection{2 Đánh giá mức độ ô nhiễm chất hũu cơ}

Bảng 3. Nồng độ ô nhiễm chất hữu cơ của chất lượng nước mặt huyện Xuân Lộc

\begin{tabular}{|c|c|c|c|c||c|c|c|c|}
\hline \multirow{2}{*}{ Thông số } & \multicolumn{4}{|c||}{ Mùa khô } & \multicolumn{4}{c|}{ Mùa mưa } \\
\cline { 2 - 9 } & Mean & Std & Min & Max & Mean & Std & Min & Max \\
\hline COD $(\mathrm{mg} / \mathrm{l})$ & 63,32 & 77,71 & 5 & 386 & 34,01 & 51,93 & 6 & 374 \\
\hline BOD $(\mathrm{mg} / \mathrm{l})$ & 35,50 & 45,47 & 3 & 220 & 18,76 & 23,45 & 3 & 164 \\
\hline
\end{tabular}

Nhu cầu oxy hóa học (COD): Kết quả phân tích cho thấy, nồng độ COD có giá trị trung bình 63,32 \pm $7,71(\mathrm{mg} / \mathrm{l})$ vào mùa khô và có giá trị $34,01 \pm 51,93(\mathrm{mg} / \mathrm{l})$ vào mùa mưa, nồng độ ô nhiễm có xu hướng giảm về mùa mưa. So sánh với QCVN 08:2015-MT/BTNMT A2 $(15 \mathrm{mg} / \mathrm{l})$ có 19/30 mẫu trong các đợt 1 và đợt 2 vào mùa khô, có $14 / 30$ mẫu đợt 1 và đợt 2 vào mùa mưa vượt quy chuẩn. Các vị trí ô nhiễm như Suối Lạnh (NM03) tiếp nhận nước thải khu dân cư và hộ chăn nuôi xã Xuân Trường, nhánh suối Gia Huynh (NM12) đoạn chảy qua xã Xuân Thành tiếp nhận nước thải nhà máy chế biến tinh bột mì Tân Hợp Thành và các hộ chăn nuôi xã Xuân Thành, nhánh Suối Khỉ (NM29) tiếp nhận trực tiếp nước thải từ trại chăn nuôi heo Kim Ngọc Phan, nhánh Suối Mè (NM08) tiếp nhận nước thải Trang trại heo Nguyệt Đức,...

Nhu cầu oxy sinh hóa $\left(\mathrm{BOD}_{5}\right)$ : Tương tự $\mathrm{COD}$ nồng độ $\mathrm{BOD}_{5}$ có xu hướng giảm vào mùa mưa, giá trị trung bình $35,50 \pm 45,47(\mathrm{mg} / \mathrm{l})$ vào mùa khô và có giá trị $18,76 \pm 23,45(\mathrm{mg} / \mathrm{l})$ vào mùa mưa. Trong đó hàm lượng $\mathrm{BOD}_{5}$ cao nhất tại các vị trí NM03, NM08, NM09, NM11, NM12, NM28, NM29. Đây là những vị trí tiếp nhận khá nhiều nước thải từ các trang trại chăn nuôi heo có quy mô lớn làm tăng nhu cầu oxy sinh hóa tại đây. Tại hồ Núi Le và Hồ Gia Ui hầu hết các vị trí lấy mẫu ở 4 đợt, nồng độ COD đều đạt quy chuẩn QCVN 08:2015-MT/BTNMT cột $\mathrm{A} 2$ (15mg/l). Riêng vị trí thượng nguồn Hồ Núi Le (NM15) hàm lượng $\mathrm{COD}$ tăng nhẹ vượt quy chuẩn cho phép khoảng 1,5 lần vào mùa mưa và vị trí gần cống xả hồ Gia Ui (NM17) hàm lượng COD tăng nhẹ vượt quy chuẩn cho phép khoảng 1,1 lần. Hàm lượng $\mathrm{BOD}_{5}$ tại $\mathrm{Hồ}$ Núi Le và Hồ Gia Ui, hầu hết đạt quy chuẩn QCVN 08:2015-MT/BTNMT cột A2 (6 mg/l) cả 2 mùa. Riêng đợt 2 mùa mưa các vị trí thượng nguồn vào Hồ Núi Le (NM15), gần cống xả Hồ Gia Ui (NM17) và vị trí thượng nguồn vào hồ Gia Ui (NM18) hàm lượng $\mathrm{BOD}_{5}$ tăng nhẹ vượt quy chuẩn cho phép khoảng 1,1 1,5 lần.

\subsection{3 Đánh giá mức độ ô nhiễm chất dinh duỡng}

Bảng 4. Nồng độ ô nhiễm chất dinh dưỡng của nước mặt huyện Xuân Lộc

\begin{tabular}{|c|c|c|c|c||c|c|c|c|}
\hline \multirow{2}{*}{ Thông số } & \multicolumn{4}{|c||}{ Mùa khô } & \multicolumn{4}{c|}{ Mùa mưa } \\
\cline { 2 - 11 } & Mean & Std & Min & Max & Mean & Std & Min & Max \\
\hline$\left(\mathrm{N}-\mathrm{NH}_{4}{ }^{+}\right)(\mathrm{mg} / \mathrm{l})$ & 13,28 & 21,86 & 0,23 & 90,05 & 4,26 & 6,97 & 0,22 & 51,51 \\
\hline$\left(\mathrm{N}-\mathrm{NO}_{2}{ }^{-}\right)(\mathrm{mg} / \mathrm{l})$ & 0,07 & 0,1 & 0 & 0,48 & 0,09 & 0,14 & 0 & 0,87 \\
\hline$\left(\mathrm{N}-\mathrm{NO}_{3}{ }^{-}\right)(\mathrm{mg} / \mathrm{l})$ & 3,31 & 7,67 & 0,48 & 64,45 & 2,06 & 2,30 & 0 & 17,6 \\
\hline$\left(\mathrm{P}_{-} \mathrm{PO}_{4}{ }^{3-}\right)(\mathrm{mg} / \mathrm{l})$ & 2,54 & 4,18 & 0,01 & 17,71 & 1,28 & 2,66 & 0 & 13,2 \\
\hline
\end{tabular}




\section{NGHIÊN CUUU HIÊN TRẬ Ô NHIỄM VÀ ĐÊ XUÂTT CÁC GIẢI PHÁP BẢO VỆ CHẤT LƯỢNG NƯỞC MẶT TRÊN ĐỊA BÀN HUYỆN XUÂN LỘC, TỈNH ĐỒNG NAI}

Bảng 4 hàm lượng Amoni $\left(\mathrm{N}^{-\mathrm{NH}_{4}}{ }^{+}\right)$biến động khá nhiều và có xu hướng giảm từ mùa khô sang mùa mưa, giá trị trung bình $13,28 \pm 21,86(\mathrm{mg} / \mathrm{l})$ vào mùa khô và $4,26 \pm 6,97(\mathrm{mg} / \mathrm{l})$ vào mùa mưa. So sánh với QCVN 08:2015-MT/BTNMT A2 $(0.3 \mathrm{mg} / \mathrm{l})$, hầu hết các vị trí lấy mẫu đều vượt quy chuẩn cho phép: Có $28 / 30$ mẫu vượt quy chuẩn ở các đợt lấy mẫu cả mùa mưa và mùa khô. Cao nhất tại các vị trí NM03, NM06, NM08, NM09, NM11, NM28, NM29. Đây là các sông, suối có nguồn tiếp nhận từ nhiều nước thải sinh hoạt của dân cư, chăn nuôi trên địa bàn huyện, nguyên nhân là do sông, suối tiếp nhận nước thải chăn nuôi, nước thải sản xuất, sinh hoạt của người dân. Tại Hồ Núi Le và Hồ Gia Ui so sánh với QCVN 08:2015MT/BTNMT A2 $(0.3 \mathrm{mg} / \mathrm{l})$, các vị trí lấy mẫu đều có hàm lượng Amoni hơi vượt quy chuẩn cho phép ở các vị trí thượng nguồn.

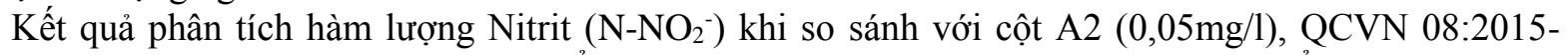
MT/BTNMT có $13 / 30$ vị trí vượt quy chuẩn vào mùa khô và có $10 / 30$ vị trí vượt quy chuẩn vào mùa mưa, biến động giữa mùa khô vừa mùa mưa không đáng kể. Cao nhất tại các vị trí NM03, NM06, NM08, NM09, NM11, NM25, NM25, NM28, NM29. Tại Hồ Núi Le và Hồ Gia Ui, nồng độ Nitrite tại các vị trí lấy mẫu đều đạt quy chuẩn QCVN 08:2015-MT/BTNMT A2 (0,05 mg/l).

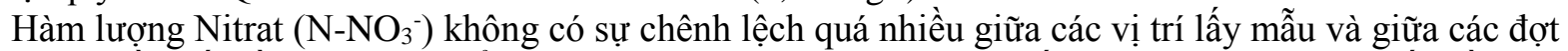
lấy mẫu và hầu hết đều đạt quy chuẩn cho phép, chỉ có vị trí NM12 (Suối Lò Cỏ) và NM28 (Suối Cầu) có hàm lượng khá cao. Đây là các nhánh suối tiếp nhận chất thải từ các cơ sở chăn nuôi và nhà máy chế biến nông sản (chế biến tinh bột mì), hoạt động sản xuất nông nghiệp (trồng chuối, bắp, khoai mì,..) và trồng cây công nghiệp như (Cao su, điều,...), giá trị trung bình $3,31 \pm 7,67(\mathrm{mg} / \mathrm{l})$ vào mùa khô và $2,06 \pm 2,30$ $(\mathrm{mg} / \mathrm{l})$ vào mùa mưa. Tại Hồ Núi Le và Hồ Gia Ui, hàm lượng Nitrat đều đạt quy chuẩn cho phép trong tất cả các đợt lấy mẫu.

Hàm lượng Phosphat $\left(\mathrm{P}^{-} \mathrm{PO}_{4}{ }^{3-}\right)$ có xu hướng giảm từ mùa khô sang mùa mưa, giá trị trung bình 2,54 \pm $4,18(\mathrm{mg} / \mathrm{l})$ vào mùa khô và $1,28 \pm 2,66(\mathrm{mg} / \mathrm{l})$ vào mùa mưa. Hàm lượng Phosphat cao nhất tại các vị trí NM03, NM06, NM08, NM09, NM11, NM13, NM28, NM29, đây là các vị trí tiếp nhận nguồn nước thải từ các trang trại chăn nuôi lớn trên địa bàn huyện Xuân Lộc.

Tại Hồ Núi Le và Hồ Gia Ui hàm lượng Photphat đều đạt quy chuẩn QCVN 08:2015-MT/BTNMT A2 $(0.3 \mathrm{mg} / \mathrm{l})$, riêng vị trí thượng nguồn và hồ Núi Le (NM15), hàm lượng Photphat tăng nhẹ, vượt giới hạn cho phép khoảng 1,25 lần.

\subsection{4 Đánh giá mức độ ô nhiễm vi sinh}

Bảng 5. Nồng độ ô nhiễm vi sinh của nước mặt huyện Xuân Lộc

\begin{tabular}{|c|c|c|c|c||c|c|c|c|}
\hline \multirow{2}{*}{ Thông số } & \multicolumn{4}{|c||}{ Mùa khô } & \multicolumn{4}{c|}{ Mùa mưa } \\
\cline { 2 - 9 } & Mean & Std & Min & Max & Mean & Std & Min & Max \\
\hline $\begin{array}{c}\text { Coliform } \\
\text { (MPN/100ml) }\end{array}$ & 13,915 & 19,204 & 700 & 90,000 & 14,835 & 18,403 & 1,000 & 85,000 \\
\hline
\end{tabular}

Kết quả phân tích cho thấy nồng độ Coliform là khá lớn, giá trị trung bình $13.915 \pm 19.204(\mathrm{mg} / \mathrm{l})$ vào mùa khô và có giá trị $14.403 \pm 18.403(\mathrm{mg} / \mathrm{l})$ vào mùa mưa. So sánh với QCVN 08:2015-MT/BTNMT cột A2 (5.000 MPN/100ml) có 12/30 vị trí vượt quy chuẩn cho phép. Cao nhất tại các vị trí NM03, NM06, NM08, NM09, NM11, NM13, NM14, NM28, NM29. Tại các vị trí lấy mẫu tại 2 hồ cấp nước (Hồ Núi Le và Hồ Gia Ui) đều đạt QCVN 08:2015-MT/BTNMT A2 (5.000 MPN/100ml).

\subsection{5 Đánh giá hiện trạng hiện trạng chất luợng nước mặt huyện Xuân Lộc theo chỉ số chất luợng nuớc WQI.}

Chất lượng nước theo chỉ số WQI có sự phân hóa theo từng vùng khác nhau trên địa bàn huyện Xuân Lộc. Nhìn chung các hồ cấp nước (hồ Gia Ui và hồ Núi Le) có chất lượng nước tốt phục vụ cho mục đích cấp nước sinh hoạt chiếm $7 \%$, khoảng $27 \%$ đạt chất lượng nước dùng cho mục đích cấp nước sinh hoạt nhưng cần các biện pháp xử lý phù hợp tại các vị trí: Sông La Ngà đoạn qua xã Xuân Bắc, Suối Tre, suối Rết, suối chảy qua xã Bảo Hoà và các vị trí thượng nguồn vào hồ Núi Le và hồ Gia Ui, khoảng $23 \%$ đạt quy chuẩn cho mục đích tưới tiêu và các mục đích khác, khoảng $30 \%$ đạt chất lượng nước sử dụng nước cho giao thông thủy và các mục đích khác tại các vị trí NM02, NM06, NM20, NM21, NM23, NM24, NM27, 
NM30, khoảng 13\% tại các vị trí NM03, NM10, NM12, NM13, NM14, NM22, NM25, NM26, NM29 bị ô nhiễm nặng cần có biện pháp trong xử lý trong tương lai. Nguyên nhân tại các vị trí này tiếp nhận nước thải trực tiếp từ các trang trại chăn nuôi lớn trên địa bàn huyện.

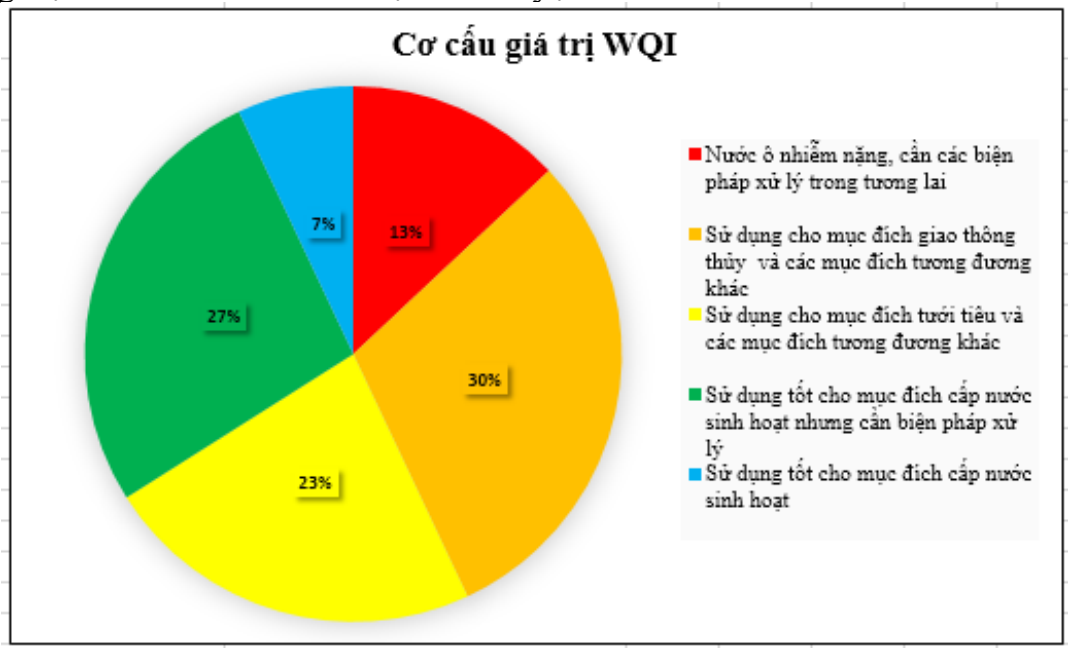

Hình 3. Hiện trạng chất lượng nước theo chỉ số WQI
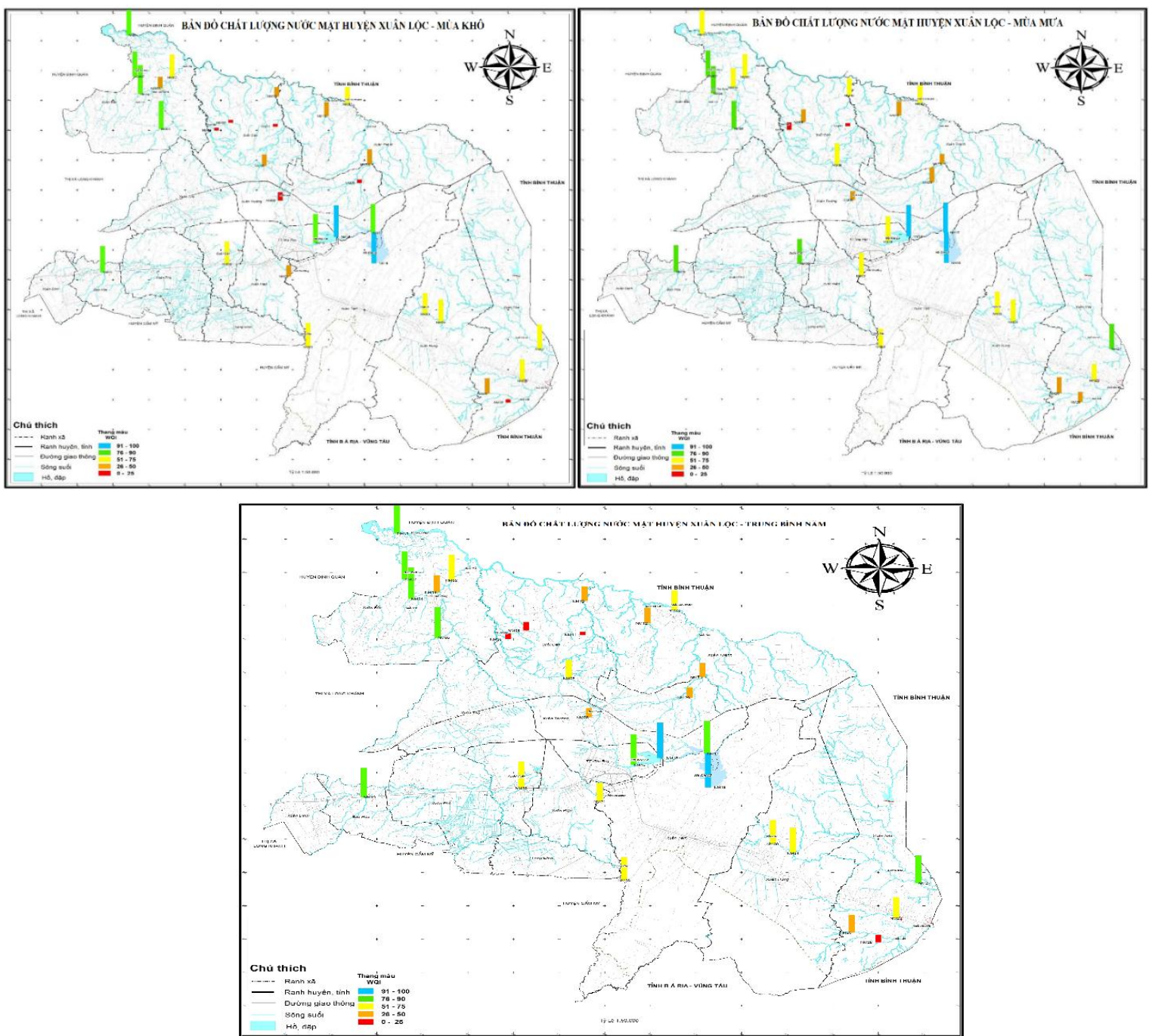

Hình 4. Bản đồ chất lượng nước mặt huyện Xuân Lộc (Mùa khô, mùa mưa, trung bình năm) 


\section{NGHIÊN CUUU HIÊN TRẬ Ô NHIỄM VÀ ĐÊ XUÂTT CÁC GIẢI PHÁP BẢO VỆ CHẤT LƯỢNG NƯỞC MẶT TRÊN ĐỊA BÀN HUYỆN XUÂN LỘC, TỈNH ĐỒNG NAI}

Qua hình 3 cho thấy chất lượng nước nước mặt huyện Xuân Lộc, Đồng Nai có sự thay đổi hàm lượng các chất ô nhiễm, có xu hướng giảm từ mùa khô sang mùa mưa, nguyên nhân vì phần lớn các sông, suối trên địa bàn huyện thường ngắn và dốc, nên khả năng giữ nước rất kém, nghèo kiệt vào mùa khô, việc các cơ sở sản xuất và các trang trại chăn nuôi xả thải sẽ gây tù đọng, khả năng thoát nước không cao ở các sông suối cạn nước, lưu lượng dòng chảy thấp gây gia tăng hàm lượng các chất ô nhiễm. Vào mùa mưa, mực nước các sông suối dâng cao, cùng với việc xả thải một lượng lớn nước thải tại các cơ sở sản xuất, các trang trại chăn nuôi cũng gây ô nhiễm trên diện rộng ở các sông suối tiếp nhận chất thải nhưng mức độ ô nhiễm thấp hơn mùa khô vì khả năng tự làm sạch cao do có dòng chảy mạnh.

\section{2 Đánh giá khả năng tiếp nhận nước thải của hệ thống sông, suối trên địa bàn huyện Xuân Lộc}

Dựa trên kết quả phân tích các chỉ tiêu ô nhiễm trong nước mặt và bản đồ hiện trạng chất lượng nước mặt trên địa bàn huyện Xuân Lộc, đánh giá bước đầu về khả năng tiếp nhận nước thải của hệ thống sông, suối trên địa bàn huyện Xuân Lộc như sau:

\section{Vào mùa khô:}

Khu vực các sông, suối bị ô nhiễm nặng, không còn khả năng tiếp nhận nước thải đối với các chỉ tiêu: $\mathrm{DO}, \mathrm{BOD}_{5}, \mathrm{COD}$, Amoni, Nitrit, Phosphat và Coliforms: Khu vực suối Lạnh qua khu vực xã Xuân Trường (NM03), nhánh suối Mè (NM08) ở xã Suối Cao (NM09), nhánh suối nhỏ chảy ra suối Gia Huynh khu vực Xuân Thành, nhánh suối Cầu qua xã Xuân Hoà (NM28)và nhánh suối Khỉ (NM29) chảy qua xã Xuân Trường.

Khu vực các sông, suối còn khả năng tiếp nhận nước thải: Suối cầu số 1 trên đường Xuân Thành - Suối Cao - Xuân Bắc (NM10), Suối Lò Cỏ (NM12) chảy ra suối Gia Huynh (NM13), Suối Khỉ (NM13), Suối Tam Bung (NM14), Suối Bà Rùa (NM25, NM26), Suối Rết (NM02), Suối qua xã Suối Cát (NM20), Suối Gia Măng (NM21), Suối Gia Huynh (NM22), Sông Ray (NM23), Suối Oi (NM24), Sông Ui (NM30). Khu vực Sông La Ngà (NM01), Suối Tre (NM04), Suối Rết (NM05), Suối Tà Rùa(NM07), Suối qua xã Bảo Hoà (NM19), Suối Gia Ui (NM27).

\section{Vào mùa mưa:}

Hai khu vực Suối Mè (NM09) và nhánh suối nhỏ chảy ra suối Gia Huynh khu vực Xuân Thành (NM11) không còn khả năng tiếp nhận nước thải đối với các chỉ tiêu: $\mathrm{BOD}_{5}, \mathrm{COD}, \mathrm{Amoni}$, TSS, Coliforms. Các vị trí còn lại còn khả năg tiếp nhận nước thải.

\section{Đánh giá chung: Trung bình năm}

Khu vực các sông, suối bị ô nhiễm nặng, không còn khả năng tiếp nhận nước thải, cần hạn chế chăn nuôi ở khu vực này: nhánh suối Mè (NM08, NM09) ở xã Suối Cao, nhánh suối nhỏ chảy ra suối Gia Huynh khu vực Xuân Thành (NM11), nhánh suối Cầu qua xã Xuân Hoà (NM28) không còn tiếp nhận các chỉ tiêu: $\mathrm{BOD}_{5}, \mathrm{COD}$, Amoni, TSS, Phosphat, Coliforms.

Khu vực các sông, suối còn khả năng tiếp nhận nước thải: Khu vực Suối cầu số 1 trên đường Xuân Thành - Suối Cao - Xuân Bắc (NM10), Suối Lò Cỏ (NM12) chảy ra suối Gia Huynh, Suối Khỉ (NM13), Suối Tam Bung (NM14), Suối Bà Rùa (NM25, NM26), Suối Rết (NM02), Suối qua xã Suối Cát (NM20), Suối Gia Măng (NM21), Suối Gia Huynh (NM22), Sông Ray (NM23), Suối Oi (NM24), Sông Ui (NM30). Khu vực Sông La Ngà, Suối Tre, Suối Rết, Suối Tà Rùa, suối qua xã Bảo Hoà, Suối Gia Ui. Tại các vị trí còn lại (Hồ Núi Le và Hồ Gia Ui) nghiêm cấm xả thải nước thải.

\section{3 Đánh giá hiện trạng các nguồn xả thải trên địa bàn huyện Xuân Lộc, Đồng Nai}

\subsubsection{Nồng độ các chỉ tiêu ô nhiễm}

Kết quả phân tích so sánh với quy chuẩn hiện hành như QCVN 62-MT:2016/BTNMT cột A2 về nước thải chăn nuôi, QCVN 40:2011/BTNMT cột A2 về nước thải công nghiệp, QCVN 14:2008/BTNMT cột A2 về nước thải công nghiệp, QCVN 28:2010/BTNMT cột A2 về nước thải y tế, cho thấy hầu hết nước thải các cơ sở chăn nuôi và giết mổ đều có các thông số vượt chuẩn quy định. Với chất hữu cơ (BOD5, $\mathrm{COD})$, chất dinh dưỡng $(\mathrm{N}, \mathrm{P})$, TSS, vi sinh có hàm lượng rất cao trong nước thải, tiếp theo là các nguồn thải các chợ, cơ sở sản xuất đều có các chỉ tiêu vượt giới hạn quy chuẩn cho phép, chỉ có nước thải y tế là 
nằm trong giới hạn cho phép. Nước thải của các nhóm ngành chỉ mang tính tương đối, do phụ thuộc vào lưu lượng nước thải và tính chất nước thải của từng cơ sở.

Bảng 6. Nồng độ các chỉ tiêu ô nhiễm trong nước thải của các nguồn thải huyện Xuân Lộc

\begin{tabular}{|c|c|c|c|c|c|c|c|c|c|c|c|}
\hline \multirow{2}{*}{ TT } & \multirow{2}{*}{$\begin{array}{l}\text { Loại } \\
\text { hình }\end{array}$} & \multicolumn{8}{|c|}{ Nồng độ trung bình (mg/l) } & & \\
\hline & & TSS & COD & $\mathrm{BOD}_{5}$ & $\mathrm{~T}-\mathrm{N}$ & $\mathrm{T}-\mathrm{P}$ & $\mathrm{NH}_{4}^{+}$ & $\mathrm{NO}_{2}^{-}$ & $\mathrm{NO}_{3}^{-}$ & $\mathrm{PO}_{4}{ }^{3-}$ & Coliform \\
\hline 1 & $\begin{array}{l}\text { Chăn } \\
\text { nuôi }\end{array}$ & $\begin{array}{c}170,5 \\
\pm \\
119,8\end{array}$ & $\begin{array}{c}520,9 \\
\pm \\
559,8\end{array}$ & $\begin{array}{c}363,8 \\
\pm \\
392,5\end{array}$ & $\begin{array}{c}133,8 \\
\pm \\
124,3\end{array}$ & $\begin{array}{c}16,7 \\
\pm \\
8,5\end{array}$ & $\begin{array}{c}120,7 \\
\pm \\
125,0\end{array}$ & $\begin{array}{c}0,4 \\
\pm \\
0,2\end{array}$ & $\begin{array}{c}3,6 \\
\pm \\
3,8\end{array}$ & $\begin{array}{c}13,5 \\
\pm \\
7,9\end{array}$ & $\begin{array}{c}404.644,4 \\
\pm \\
218.150,1\end{array}$ \\
\hline 2 & $\begin{array}{c}\text { Cơ sở } \\
\text { sản xuất }\end{array}$ & $\begin{array}{l}79,8 \pm \\
101,9\end{array}$ & $\begin{array}{c}126,6 \pm \\
186,6\end{array}$ & $\begin{array}{l}88,6 \pm \\
130,6\end{array}$ & $\begin{array}{c}23,7 \pm \\
29,9\end{array}$ & $\begin{array}{c}4,5 \pm \\
5,8\end{array}$ & $\begin{array}{c}19,5 \pm \\
27,8\end{array}$ & $\begin{array}{c}0,7 \pm \\
0,3\end{array}$ & $\begin{array}{c}4,8 \pm \\
3,1\end{array}$ & $\begin{array}{c}1,6 \pm \\
0,8\end{array}$ & $\begin{array}{l}29.170 \pm \\
45.721,6\end{array}$ \\
\hline 3 & Chợ & $\begin{array}{c}120 \pm \\
56,7\end{array}$ & $\begin{array}{l}304,4 \\
\pm 196\end{array}$ & $\begin{array}{l}198 \pm \\
140,2\end{array}$ & $\begin{array}{c}46,2 \pm \\
17,9\end{array}$ & $\begin{array}{r}11,7 \\
\pm 5,4\end{array}$ & $\begin{array}{c}39,6 \pm \\
17,5\end{array}$ & $\begin{array}{c}0,06 \pm \\
0,04\end{array}$ & $\begin{array}{c}4,3 \pm \\
1,6\end{array}$ & $\begin{array}{c}8,0 \pm \\
4,7\end{array}$ & $\begin{array}{l}234.300 \pm \\
188.536,9\end{array}$ \\
\hline 4 & Y tế & $\begin{array}{c}31 \pm \\
5,6 \\
\end{array}$ & $\begin{array}{c}91,5 \pm \\
9,1 \\
\end{array}$ & $\begin{array}{c}64 \pm \\
5,6 \\
\end{array}$ & $\begin{array}{c}14,2 \pm \\
7,4 \\
\end{array}$ & $\begin{array}{c}0,9 \pm \\
0,3 \\
\end{array}$ & $\begin{array}{c}6,6 \pm \\
6,4 \\
\end{array}$ & $\begin{array}{c}0,1 \pm \\
0,1 \\
\end{array}$ & $\begin{array}{c}6,3 \pm \\
0,2 \\
\end{array}$ & $\begin{array}{c}0,17 \pm \\
0,05\end{array}$ & $\begin{array}{l}535 \pm \\
190,9 \\
\end{array}$ \\
\hline 5 & $\begin{array}{c}\text { Cơ sở } \\
\text { dịch vụ }\end{array}$ & $\begin{array}{c}92,6 \pm \\
11,3\end{array}$ & $\begin{array}{c}223 \pm \\
24,5\end{array}$ & $\begin{array}{c}156 \pm \\
13,7\end{array}$ & $\begin{array}{c}16,9 \pm \\
10,6\end{array}$ & $\begin{array}{c}3,1 \pm \\
0,3\end{array}$ & $\begin{array}{c}13,1 \pm \\
11,2\end{array}$ & $\begin{array}{c}0,17 \pm \\
0,09\end{array}$ & $\begin{array}{c}6,7 \pm \\
7,1 \\
\end{array}$ & $\begin{array}{c}2,3 \pm \\
0,4\end{array}$ & $\begin{array}{c}595.000 \pm \\
182.962\end{array}$ \\
\hline
\end{tabular}

\subsubsection{Lưu lượng và tải lượng ô nhiếm}

Bảng 7. Lưu lượng và tải lượng các chỉ tiêu ô nhiễm của các nguồn thải

\begin{tabular}{|c|c|c|c|c|c|c|c|}
\hline \multirow{2}{*}{ Loại hình } & \multirow{2}{*}{$\begin{array}{c}\text { Lưu lượng } \\
\left(\mathrm{m}^{3} / \text { ngày }\right)\end{array}$} & \multicolumn{5}{|c|}{ Tải lương $(\mathrm{kg} / \mathrm{ngày})$} & \multirow{2}{*}{$\begin{array}{c}\text { Coliform } \\
\text { (MPN/ngày) }\end{array}$} \\
\cline { 3 - 7 } & & TSS & COD & BOD & T-N & T-P & \\
\hline Chăn nuôi & $7.144,5$ & 642,18 & 1711 & 1205 & 485,21 & 72,89 & $16,28 \times 10^{8}$ \\
\hline Cơ sở sản xuất & 2.112 & 44 & 138 & 107 & 62 & 6 & $39.166 \times 10^{5}$ \\
\hline Các chợ & 255 & 28,55 & 69,78 & 45,04 & 8,50 & 2,03 & $33,36 \times 10^{6}$ \\
\hline Y tến & 101 & 3,52 & 9,88 & 6,86 & 1,96 & 0,08 & $0,067 \times 10^{6}$ \\
\hline Các cơ sở dịch vụ & 40 & 3,66 & 9,02 & 6,29 & 0,72 & 0,12 & $23,1 \times 10^{6}$ \\
\hline
\end{tabular}

Lưu lượng xả thải trên địa bàn huyện Xuân Lộc cao nhất là nước thải chăn nuôi (gấp từ 3.38 lần so với nguồn thải kế tiếp là nước thải cơ sở sản xuất) và giảm dần theo thứ tự là chợ, y tế, dịch vụ). Trên thực tế không phải các nguồn nước thải đều được thải vào sông, suối, hồ, mà một lượng lớn nước thải được các cơ sở, hộ dân thải trực tiếp ra và cho tự thấm xuống đất.

\subsection{Các giải pháp bảo vệ và quản lý chất lượng nước mặt huyện Xuân Lộc, Đồng Nai}

\subsubsection{Giải pháp về lựa chọn các ngành nghề đầu tư}

Nguồn nước mặt trên địa bàn huyện Xuân Lộc khá phong phú, tuy nhiên các sông suối thường ngắn, dốc, khả năng giữ nước kém, lại nằm trên khu vực nghèo nước dưới đất của tỉnh Đồng Nai, do vậy, việc khai thác và sử dụng nguồn nước dưới đất ở quy mô công nghiệp trên địa bàn huyện Xuân Lộc còn rất hạn chế. Theo quyết định số 2163/QĐ-UBND ngày 09/07/2014 của UBND tỉnh Đồng Nai về ban hành danh mục dự án thuộc ngành ưu tiên thu hút đầu tư, thu hút đầu tư có điều kiện và tạm dừng thu hút đầu tư trên địa bàn tỉnh, qua đó các ngành nghề ưu tiên phát triển trên địa bàn như: Chế biến nông sản, chăn nuôi, sản xuất nông dược, trang thiết bị, dụng cụ y tế, thuốc chữa bệnh, thuốc thú y, mỹ nghệ, .....bên cạnh đó các ngành hạn chế, không đầu tư phát triển trên địa bàn huyện như: Sản xuất giấy, bột giẩy từ nguyển liệu thô; chế biến tinh bột sắn, chế biến mủ cao su chưa sơ chế, sản xuất hóa chất cơ bản, các ngành thuộc da, sơ chế da, sơ chế và nhuộm da lông thú, nhiệt điện, luyện thép, xi mạ.

\subsubsection{Giải pháp về nâng cao nhận thức cộng đồng và bảo vệ môi truờng dựa vào cộng đồng}

Thực hiện công tác tuyên truyền, giáo dục nhằm nâng cao nhận thức của cộng đồng về tầm quan trọng của bảo vệ môi trường, bảo vệ nguồn nước, khuyến khích các trang trại, hộ gia đình áp dụng sản xuất sạch hơn trong chăn nuôi, sản xuất theo tiêu chuẩn VietGap, áp dụng chính sách trợ cấp môi trường để hỗ trợ cộng đồng thực hiện các biện pháp xử lý ô nhiễm môi trường, chính sách miễn thuế sử dụng đất, cho vay vốn lãi suất thấp để xây dựng các công trình xử lý chất thải chăn nuôi, huy động sự tham gia của các ban 


\section{NGHIÊN CUUU HIÊN TRẬ Ô NHIỄM VÀ ĐÊ XUÂTT CÁC GIẢI PHÁP BẢO VỆ CHẤT LƯợNG NƯỞC MẶT TRÊN ĐỊA BÀN HUYỆN XUÂN LỘC, TỈNH ĐỒNG NAI}

ngành đoàn thể huyện Xuân Lộc tham gia các hoạt động bảo vệ môi trường chăn nuôi, tuyên truyền vận động lồng ghép các hoạt động tôn giáo với bảo vệ môi trường trong chăn nuôi dựa trên lợi thế sẵn có của huyện.

\subsubsection{Giải pháp về cơ chế chinh sách, vốn đầu tu, phát triển cở sở hạ tầng vùng chăn nuôi}

Thực hiện triển khai các chính sách hỗ trợ về vốn theo các quy định hiện hành đối với các chủ trang trại chăn nuôi đạt tiêu chuẩn quy định theo chính sách hỗ trợ, khuyến khích chủ đầu tư xây dựng các công trình xử lý chất thải chăn nuôi như: Nghị định số 04/2009/NĐ-CP ngày 14/01/2009 của Chính phủ về ưu đãi, hỗ trợ hoạt động bảo vệ môi trường; Nghị định số 69/2008/NĐ-CP ngày 30/05/2008 của Chính phủ về chính sách khuyến khích xã hội hóa đối với các hoạt động trong lĩnh vực giáo dục, dạy nghề, y tế, văn hóa, thể thao và môi trường.

\subsubsection{Giải pháp phối hợp kiểm tra, giám sát liên ngành}

Đẩy mạnh tần xuất thanh tra, kiểm tra đối với tất cả các cơ sở sản xuất, kinh doanh và chăn nuôi gia súc, gia cầm gây ô nhiễm môi trường, thành lập đoàn liên ngành phối hợp kiểm tra, xử lý các trường hợp vi phạm pháp luật về môi trường, ngăn chăn kịp thời việc xây dựng các cơ sở, trang trại chăn nuôi trái phép, đặc biệt là xây dựng trang trại chăn nuôi gia súc, gia cầm không đúng quy hoạch đã được phê duyệt, kiên quyết xử lý đối với các cơ sở, trang trại xả thải gây ô nhiễm môi trường kéo dài, gây bức xúc trong nhân dân.

\subsubsection{Giải pháp về quy mô đàn nuôi, vùng cấm và vùng chăn nuôi}

Trong khu vực đô thị, khu dân cư, vùng bảo vệ cấp nước sinh hoạt và vùng gần các con sông suối chính cấp nước cho người dân thực hiện cấm hoàn toàn hoạt động chăn nuôi mới, đối với những hộ đang chăn nuôi cần thực hiện hỗ trợ, di dời theo lộ trình vào khu vực khuyến khích chăn nuôi. Vùng cấm chăn nuôi trên địa bàn huyện Xuân Lộc gồm:

Vùng đô thị: Thị trấn Gia Ray; trung tâm các xã Xuân Tâm, Xuân Hòa, Xuân Hưng, Suối Cát, Bảo Hòa, Xuân Định, Xuân Bắc, Suối Cao, Xuân Thành, Xuân Trường, Xuân Phú, Xuân Hiệp, Xuân Thọ, Lang Minh.

Vùng bảo vệ các hồ chưa nước sinh hoạt (Núi Le, Gia Ui) trên địa bàn huyện và vùng gần các khu vực sông, suối.

Vùng chăn nuôi là vùng nằm trong quy hoạch sử dụng đất giai đoạn 2016 - 2020 và điều chỉnh quy hoạch vùng phát triển chăn nuôi và giểt mổ tập trung trên địa bàn huyện Xuân Lộc đến năm 2020, định hướng phát triển đến năm 2030 (trừ những vùng cấm chăn nuôi).

\subsubsection{Giải pháp quản lý nhà nước đối với hoạt động chăn nuôi}

Ủy ban nhân dân huyện Xuân Lộc phối hợp các cơ quan liên quan giám sát nghiêm ngặt việc chăn nuôi trong vùng cấm và vùng chăn nuôi; bảo đảm thực hiện việc di dời các trang trại gây ô nhiễm và trong khu dân cư vào khu chăn nuôii công bố công khai vùng cấm và vùng chăn nuôi của huyện, đầu tư các công trình bảo vệ môi trường; giải quyết các đơn khiếu nại, tố cáo có liên quan đến môi trường trong hoạt động chăn nuôi ở địa phương.

Tổ chức thực hiện các văn bản pháp luật về bảo vệ môi trường trong hoạt động chăn nuôi trên phạm vi địa phương. Kiến nghị UBND tỉnh xây dựng Quy chế bảo vệ môi trường đối với hoạt động chăn nuôi trong đó có nội dung: Không chăn nuôi gia súc, gia cầm trong các khu dân cu tập trung.

Quản lý môi trường chăn nuôi từ cấp xã, cơ quan quản lý nhà nước cấp xã đóng vai trò cực kỳ quan trọng và là cấp trực tiếp quản lý chăn nuôi trên địa bàn, chính vì vậy đây là cấp vừa có nhiệm vụ triển khai thực thi chủ trương chính sách của cơ quan quản lý nhà nước về quản lý môi trường đến các trang trại, hộ gia đình chăn nuôi, tuyên truyền, vận động cộng đồng tham gia quản lý môi trường trong chăn nuôi, đây cũng là cấp phát hiện và phản ánh các tồn tại trong việc áp dụng các chính sách quản lý nhà nước về môi trường trong chăn nuôi cho các cấp quản lý nhà nước cao hơn.

\subsubsection{Giải pháp về phát triển khu chăn nuôi tập trung}

Giải pháp về phát triển khu chăn nuôi tập trung, phát triển chăn nuôi phải gắn với bảo vệ môi trường và cải tạo môi trường. Chuyển đổi phương thức chăn nuôi với các giải pháp xử lý chất thải bằng các công nghệ phù hợp, áp dụng công nghệ tiên tiến, từng bước công nghiệp hóa và hiện đại hóa ngành chăn nuôi 


\section{NGHIÊN CỨU HIÊN TRẠNG Ô NHIỄM VÀ ĐỀ XUÂT CÁC GIẢI PHÁP BẢO VỆ CHÂTT LƯợNG NƯỚC MẶT TRÊN ĐỊA BÀN HUYỆN XUÂN LỘC, TỈNH ĐỒNG NAI}

theo hướng trang trại và nâng cao hiệu quả, khả năng kiểm soát dịch bệnh, nhằm giảm ô nhiễm môi trường chăn nuôi và môi trường sống. Chất thải chăn nuôi được xử lý cung cấp nguồn năng lượng sạch phục vụ cho sinh hoạt và sản xuất nông nghiệp và nông thôn.

\subsubsection{Giải pháp về vùng cấm, hạn chế thu hút đầu tu tại các khu vực xác định không còn khả năng tiếp nhận.}

Các khu vực không còn khả năng tiếp nhận các nguồn thải trên địa bàn huyện Xuân Lộc chủ yếu tại khu vực các nhánh suối bị ô nhiễm nặng cần giải pháp xử lý trong tương lai: Nhánh suối Lạnh chảy qua KDC xã Xuân Trường, nhánh suối Mè chảy qua khu chăn nuôi xã Suối Cao, Suối Lò Cò, suối Khỉ qua khu chăn nuôi Xuân Thành, Xuân Trường, Suối Bà Rùa, Suối Cầu, Suối Khỉ qua khu chăn nuôi xã Xuân Hoà, Xuân Hưng. Các khu vực này không thực hiện thu hút đầu tư các cơ sở sản xuất, ngành nghề có phát sinh chất thải lớn và tiến hành các giải pháp ngăn chặn, xử lý kịp thời các cơ sở xả thải gây ô nhiễm ở các khu vực này: cải tạo các công trình BVMT đảm bảo xả thải đạt chuẩn theo quy định, buộc di dời, đóng cửa nếu cơ sở vi phạm nhiều lần, không khắc phục. Cấm chăn nuôi vùng bảo vệ các hồ chứa nước sinh hoạt (Núi Le, Gia Ui) trên địa bàn huyện và vùng gần các khu vực sông, suối.

\subsubsection{Các giải pháp công nghệ}

Áp dụng công nghệ xử lý nước thải và xây dựng các mô hình xử lý phù hợp với từng loại hình doanh nghiệp trên địa bàn huyện, Các doanh nghiệp lớn cũng đã đầu từ xây dựng HTXLNT nhưng phần lớn các cơ sở sản xuất, kinh doanh, dịch vụ trên địa bàn huyện vẫn chưa đầu tư HTXLNT vì là các cơ sở có quy mô nhỏ lẻ, hộ gia đình nước thải phát sinh ít chiếm phần lớn trên tổng số các cơ sở sản xuất. Nước thải phát sinh chủ yếu xử lý bằng bể tự hoại hoặc tự thấm. Vì vậy cần áp dụng công nghệ xử lý nước thải phù hợp với từng loại nước thải của các doanh nghiệp SXKD.

+ Công nghệ xử lý nước thải y tế

+ Công nghệ xử lý nước thải chợ

+ Công nghệ xử lý nước thải lò giết mổ

Xử lý nước thải chăn nuôi: Việc lựa chọn công nghệ xử lý nước thải trong chăn nuôi heo của huyện dựa trên thành phần, tính chất đặc trưng của chất thải để ứng dụng các biện pháp xử lý đạt hiệu quả:

- Nước thải chăn nuôi có mức độ ô nhiễm rất cao, đặc biệt là $\mathrm{BOD}, \mathrm{COD}, \mathrm{SS}$, Nitơ, Phospho, vi sinh vật gây bệnh,...Vì vậy, phải kết hợp tổng thể các phương pháp cơ, lý và sinh để xử lý nước thải chăn nuôi.

- Hàm lượng chất hữu cơ, dinh dưỡng rất cao trong nước thải chăn nuôi cũng là vấn đề đáng quan tâm, vì vậy áp dụng phương pháp sinh học là phù hợp nhất.

Tùy theo điều kiện kinh tế, địa hình khu chăn nuôi và quy mô công suất chăn nuôi mà ta có thể áp dụng kết hợp một trong các phương thức sau: áp dụng phương thức chăn nuôi mới bằng đệm lót sinh học, tính toán hợp lý khẩu phần ăn, tách nước thải và phân heo để sử dụng phân cho ủ phân compost, chăn nuôi kết hợp mô hình VAC, VACR (Sử dụng hồ sinh học để nuôi cá, tưới cây), sử dụng hầm biogas nắp cố định hình vòm hầm biogas phủ bạt nhựa HDPE, hầm biogas Composite.

\section{KẾT LUẬA}

Hiện trạng chất lượng môi trường nước mặt tại các sông, suối trên địa bàn huyện đang có dấu hiệu ô nhiễm về dinh dưỡng, hữu cơ và vi sinh tại những nhánh sông, suối ở các khu vực tập trung nhiều các trang trại chăn nuôi có quy mô lớn như khu vực các xã Suối Cao, Xuân Thành, Xuân Bắc, Xuân Hòa và Xuân Hưng.

Chất lượng nước thải phát sinh tại các cơ sở vẫn chưa đảm bảo đạt quy chuẩn hiện hành, một số cơ sở, dịch vụ và chăn nuôi nước thải không được xử lý hoặc xử lý chưa hiệu quả. Cụ thể, khảo sát lấy mẫu phân tích tại 70 cơ sở, có đến 61 cơ sở phát sinh nước thải có các chỉ tiêu phân tích không đạt giá trị quy chuẩn cho phép, còn lại 9 cơ sở có chất lượng nước thải đạt giá trị quy chuẩn cho phép.

Vấn đề gây bức xúc nhất hiện nay là hoạt động chăn nuôi trong khu dân cư cùng với việc xử lý chất thải không hiệu quả gây ô nhiễm mùi, ô nhiễm nguồn nước mặt trên địa huyện ảnh hưởng đến đời sống dân cư và sản xuất nông nghiệp. Trước tình trạng đó, cần phải áp dụng những giải pháp và công nghệ xử lý ô nhiễm trước mắt và lâu dài để có thể áp dụng cho các cơ sở chăn nuôi ở mọi quy mô và hình thức nhằm góp phần phát triển một ngành chăn nuôi bền vững theo hướng công nghiệp hóa. 


\section{NGHIÊN CUUU HIÊN TRẬ Ô NHIỄM VÀ ĐÊ XUÂTT CÁC GIẢI PHÁP BẢO VỆ CHẤT LƯợNG NƯỞC MẶT TRÊN ĐỊA BÀN HUYỆN XUÂN LỘC, TỈNH ĐỒNG NAI}

\section{LỜI CẢM ƠN}

Bài báo này được xây dựng dựa trên đề tài cấp cơ sở "Điều tra, đánh giá hiện trạng ô nhiễm và đề xuất các giải pháp bảo vệ môi trường trong hoạt động sản xuất, kinh doanh, dịch vụ và chăn nuôi trên địa bàn huyện Xuân Lộc" của Trung tâm Kỹ thuật Tài nguyên Môi trường và Biển. Chúng tôi xin chân thành cảm ơn sự giúp đỡ của nhà trường.

\section{TÀI LIỆU THAM KHẢO}

[1] Cục thống kê tỉnh Đồng Nai, "Niên giám thống kê năm 2016”, 2017.

[2] Sở Tài nguyên và Môi trường tỉnh Đồng Nai, báo cáo tổng hợp "Báo cáo hiện trạng môi truờng tỉnh Đồng Nai giai đoạn 2011 - 2015”, 2015.

[3] Tổng cục môi trường, phương pháp tính toán chỉ số chất lượng nước (WQI) áp dụng cho lưu vực sông Việt Nam, Hà Nội, 2011.

[4] UBND huyện Xuân Lộc, "Báo cáo kết quả thực hiện nhiệm vu kinh tế - xã hội, quốc phòng - an ninh năm 2016 và muc tiêu, nhiệm vụ, giải pháp chủ yếu năm 2017”, 2017.

[5] UBND tỉnh Đồng Nai, Quyết định số 2325/ QĐ-UBND "Ban hành chương trình bảo vệ môi truờng tỉnh Đồng Nai giai đoạn 2016 - 2020”, 2016.

[6] UBND tỉnh Đồng Nai, Quyết định số 2325/ QĐ-UBND "Phê duyệt quy hoạch vùng phát triển chăn nuôi, các cơ sở giết mổ tập trung giai đoạn 2009 - 2015 và định huớng đến năm 2020 huyện Xuân Lộc, tỉnh Đồng Nai”, 2009.

[7] Dương Thanh Nga, Đánh giá hiện trạng, phân tích diễn biến chất lượng nước mặt tỉnh Nghệ An được thực hiện từ giai đoạn 2010 đến 2012. Luận văn thạc sỹ Khoa học Môi truờng, ĐH KHTN, 2012.

[8] Huỳnh Thị Minh Hằng, Nguyễn Thanh Hùng, Nguyễn Văn Dũng, Quản lý thống nhất và tổng hợp các nguồn thải gây ô nhiễm trên lưu vực hệ thống sông Đồng Nai”. Tạp chi Phát triển KHCN, Tập 9, Môi trường và Tài nguyên, 2006.

[9] Trần Thị Kim Lan, Ảnh hưởng của hoạt động kinh tế - xã hội đến chất lượng nước sông Phan, tỉnh Vĩnh Phúc. Luận văn thạc sỹ khoa học Môi truờng, ĐHKHTN, 2012.

[10] Lê Mạnh Tân, Đinh Quang Toàn, Đánh giá tổng quan nguồn thải gây ô nhiễm trên lưu vực hệ thống sông Đồng Nai đoạn qua tỉnh Bình Dương. Tạp chi Đại học Thủ Dầu Một, số 1-2011, 2011.

Ngày nhận bài: 01/4/2018

Ngày chấp nhận đăng: 25/4/2018 